\title{
DIDÁTICA DA LÍNGUA \\ E LINGUÍSTICA APLICADA: \\ DUAS PERSPECTIVAS DE \\ CONSTRUÇÃO DE OBJETOS \\ DE ENSINO
}

\section{DIDÁTICA DE LA LENGUA Y LINGÜÍSTICA APLICADA: DOS PERSPECTIVAS DE CONSTRUCCIÓN DE OBJETOS DE ENSEÑANZA}

\author{
DIDACTICS OF LANGUAGE AND APPLIED LINGUISTICS: TWO PERSPECTIVES OF \\ CONSTRUCTION OF TEACHING OBJECTS
}

Marcos Bispo dos Santos*

Universidade do Estado da Bahia

\begin{abstract}
RESUMO: Neste texto, apresenta-se uma análise da forma como se dá a construção de objetos de ensino pela linguística aplicada, tendo o ensino de gramática como recorte temático. O objetivo é identificar se seu modo de proceder se coaduna com os princípios teórico-metodológicos das didáticas geral e da língua. Distinguem-se duas concepções da linguística como ciência aplicada: uma linguística aplicada lato sensu, voltada para a aplicação das teorias linguísticas ao ensino de língua, e outra, stricto sensu, que se volta para o estudo de problemas que envolvem o uso da linguagem em contextos reais. Inicialmente, apresentam-se os fundamentos da didática geral, aos quais a didática da língua, como disciplina específica, deve estar conectada. Em seguida, analisam-se propostas da linguística aplicada lato sensu para uma abordagem descritivista da gramática na educação básica, destacando-se os paradoxos que as atravessam. Concluiu-se que a linguística aplicada lato sensu ignora a didática como ciência da prática de ensinar, em favor do aplicacionismo, ou seja, a transferência dos saberes científicos ao contexto escolar e à formação de professores.
\end{abstract}

PALAVRAS-CHAVE: Didática do português. Linguística aplicada. Ensino de gramática.

RESUMEN: En este texto, se presenta un análisis de la forma como se da la construcción de objetos de enseñanza por la lingüística aplicada, teniendo la enseñanza de gramática como recorte temático. El objetivo es identificar si su modo de proceder se ajusta a los principios teórico-metodológicos de las didácticas generales y de la lengua. Se distinguen dos concepciones de la lingüística como ciencia aplicada: una lingüística aplicada lato sensu, orientada a la aplicación de las teorías lingüísticas a la enseñanza de lengua, y otra stricto sensu, que se vuelve al estudio de problemas que involucran el uso del lenguaje en contextos real. Inicialmente, se presentan los fundamentos de la didáctica general, a los que la didáctica de la lengua, como disciplina específica, debe estar conectada. A continuación, se analizan propuestas de la lingüística aplicada lato sensu para un enfoque descriptivista de la gramática en la educación básica, destacándose las paradojas que las atravesan. Se concluyó que la lingüística aplicada lato sensu ignora la 
didáctica como ciencia de la práctica de enseñar, en favor del aplicacionismo, o sea, la transferencia de los saberes científicos al contexto escolar ya la formación de profesores.

PALABRAS CLAVE: La enseñanza de portugués. Linguística aplicada. Enseñanza de gramática.

ABSTRACT: In this text, we present an analysis of the way in which the construction of teaching objects by applied linguistics takes place, focusing on the teaching of grammar. The aim of this study is to identify if the way it proceeds is in line with the theoretical and methodological principles of general and language didactics. Two conceptions of linguistics are distinguished as applied science: a lato sensu applied linguistics, focused on the application of linguistic theories to language teaching, and another stricto sensu, which turns to the study of problems involving the use of language in real contexts. Initially, the fundaments of general didactics are presented, to which the didactics of language as a specific discipline must be connected. Next, we analyze proposals of applied linguistics lato sensu for a descriptive approach of grammar in basic education, highlighting the paradoxes that permeate them. It was concluded that the applied linguistics lato sensu ignores didactics as a science of the practice of teaching, in favor of applicationism, that is, the transfer of scientific knowledge to the school context and teacher training.

KEYWORDS: Didactics of Portuguese. Applied Linguistics. Grammar teaching.

\section{INTRODUÇÃO}

O desenvolvimento de diferentes teorias linguísticas científicas chamou a atenção de muitos pesquisadores para problemas conceituais da gramática tradicional e, por extensão, para os impactos desses problemas no ensino de português na educação básica. Em geral, os linguistas atribuem a esses problemas uma razão de natureza teórica e outra de natureza metodológica.

Do ponto de vista teórico, a cientifização dos estudos gramaticais, com base em novos fundamentos epistemológicos, forjou novas concepções de língua e gramática (internalizada e descritiva) e procedeu a um reexame do aparato conceitual legado pela tradição. A ênfase numa abordagem naturalista/realista da língua como objeto de estudo científico se contrapôs à concepção de língua modelar, objeto da gramática normativa, e produziu a oposição entre língua real e língua ideal. A redefinição da gramática em bases cognitivas/biológicas desvinculou esse objeto das práticas de leitura e escrita, ao concebê-lo como um conjunto de regras que estruturam o funcionamento de uma língua, entendida como um fenômeno natural.

Do ponto de vista metodológico, os linguistas criticam a centralidade da norma padrão - codificada nas gramáticas normativas no ensino de língua portuguesa, em detrimento da diversidade própria de toda língua natural, e uma pedagogia orientada para o ensino e a aprendizagem da terminologia e taxonomia gramaticais, normas ortográficas, colocação pronominal, regência, concordância etc. As pesquisas desenvolvidas, principalmente, pela sociolinguística têm evidenciado a realidade heterogênea da língua falada, e, em função disso, muitos linguistas têm proposto o abandono da perspectiva normativa no ensino de gramática em favor de uma abordagem descritiva, que se propõe a estudar a língua "como ela é", não como deveria ser.

Neste texto, argumento que as proposições dos linguistas para o ensino constituem a face aplicada da linguística como ciência pura, uma linguística aplicada lato sensu, que toma, primordialmente, as regras da racionalidade científica moderna como referências para a construção dos objetos de ensino de português na educação básica, diferentemente do que propõe a didática da língua, uma disciplina vinculada à didática geral, com que se articula para produzir uma teoria global da prática de ensino de língua e uma engenharia didática. Sendo assim, teríamos duas perspectivas de construção de objetos de ensino de português, com profundos impactos na compreensão do que é ou deve ser o ensino dessa disciplina na educação básica e na formação de professores nos cursos de licenciatura em Letras.

Ao designar as contribuições da linguística teórica como uma ciência aplicada lato sensu, quis dintingui-la de outra compreensão de ciência aplicada, que chamarei de linguística aplicada stricto sensu, definida com um ramo inter e/ou transdisciplinar de investigações sobre problemas complexos que envolvem a linguagem em contextos reais de uso. Essa modalidade recebe o nome de 
Linguística Aplicada ${ }^{1}$ (LA) e tem como uma característica marcante a recusa do aplicacionismo teórico (MOITA LOPES, 1996, 2006; CAVALCANTI; SIGNORI, 1998; CORACINI; BERTOLDO, 2003; KLEIMAN; CAVALCANTI, 2007).

Da forma como definida aqui, a linguística aplicada lato sensu (doravante, apenas linguística aplicada) não constitui um campo coeso e sistemático de produção teórica e de investigações sobre os aspectos didáticos e pedagógicos que envolvem o ensino da língua, mas um conjunto disperso de propostas que tem origem nas diferentes disciplinas da linguística ou em diferentes perspectivas no interior de uma mesma disciplina, sem qualquer nexo obrigatório ou liame entre si. Diante desse pluralismo teórico que, consequentemente, gera um pluralismo conceitual e metodológico surgem alguns problemas: como conciliar as diferentes e dispersas propostas dos linguistas aplicados em um mesmo projeto curricular de ensino de língua? O conjunto das diferentes disciplinas científicas contempla todos os conteúdos de ensino de língua para a educação básica? Como deve ser a relação entre os saberes científicos e as políticas educacionais? Como definir os objetos de ensino de língua e sua progressão ao longo da educação básica?

A transferência de saberes a que se propõe a linguística aplicada se distingue da transposição didática, termo cunhado por Chevallard (1985) para designar o processo de transformação de conhecimentos científicos em conhecimentos didáticos. Petitjean (2008) reconhece que a formulação de Chevallard reduz as potencialidades dos conhecimentos didáticos aos limites de sua conceptualização pelas disciplinas científicas, mas entende que ele pode ser reconceitualizado para explicitar as diferenças entre os objetivos científicos e os educacionais, desde que os objetos de ensino, malgrado suas possíveis articulações com a ciência (não obrigatórias e sem relações de interdependência), sejam construídos pela didática, em função dos objetivos educacionais.

Neste texto, apresento uma análise da forma como se dá a construção de objetos de ensino pela linguística aplicada, tendo o ensino de gramática como recorte temático. O objetivo é identificar se seu modo de proceder se coaduna com os princípios teóricometodológicos das didáticas geral e da língua. Na seção "Didática geral e ciência moderna", discuto os fundamentos da didática como teoria geral do ensino aos quais as didáticas das disciplinas específicas devem estar conectadas. Na seção "A didática da língua como disciplina emergente", apresento uma breve caracterização da didática da língua, seus princípios, objetivos e problemas a serem enfrentados. Finalmente, na seção "Linguística aplicada e ensino de gramática", analiso propostas da linguística aplicada para uma abordagem descritivista da gramática na educação básica, destacando os paradoxos que as atravessam.

\section{DIDÁTICA GERAL E CIÊNCIA MODERNA}

A palavra didática procede do termo grego didaskein, que significa instruir, ensinar. Tomada em sua acepção especializada, no domínio da pedagogia, a palavra deriva da expressão Techné didaktiké, isto é, a técnica ou arte de ensinar. Essa definição chama a atenção para a clássica distinção entre arte (técnica) e ciência.

Aristóteles foi o primeiro filósofo a reconhecer diferentes tipos de ciências (episteme), distinguindo-as entre teóricas (especulativas), produtivas e práticas, de acordo com a finalidade do conhecimento produzido por elas. As teóricas tinham como fim a produção do conhecimento contemplativo, o saber pelo saber; as produtivas visavam ao conhecimento útil para a produção de objetos artesanais ou manuais, engenharia, arquitetura, além de diversas habilidades de natureza artística ou profissional; as ciências práticas, por sua vez, tinham como finalidade a produção de conhecimentos voltados para a formação do caráter e da organização sociopolítica, tendo em vista os processos de socialização.

A classificação aristotélica das ciências evidencia duas formas gerais de relação com o saber. A primeira, no quadro das ciências teóricas, concebe o saber como um fenômeno distanciado, que não tem como fim nada além da mera compreensão dos objetos de estudo. A segunda, abarcando as ciências produtivas e práticas, define o saber de modo indissociavelmente ligado a um fazer que o transcende, isto é, que vai além de si mesmo para plasmar-se nos atos das criações humanas geradoras e transformadoras da

${ }^{1}$ A LA se alinha a um movimento de redefinição das relações entre as ciências de base e as ciências aplicadas, a exemplo do que aconteceu com a antropologia aplicada (BASTIDE, 2009) e com a psicologia da educação (COLL, 1999), segundo o qual a ciência aplicada deixa de ser concebida como aquela que se encarrega da aplicação das teorias puras e passa a conceber o contexto social como espaço gerador de problemas e contingências não contempladas pela racionalidade das ciências de base. 
natureza, da cultura e do próprio homem. Nessa segunda acepção, o saber pressupõe, inexoravelmente, a existência de relações contextuais nas quais os sujeitos o acionam e o transformam para viabilizar os meios necessários ao alcance de determinados fins. Nessa via de mão dupla, a didática só pode enveredar-se pela segunda forma de relação com o saber, uma vez que, para sua constituição, concorrem aspectos de natureza epistemológica (saberes), axiológica (valores) e praxiológica (técnica e política).

As críticas de Bacon (1561-1626) à concepção aristotélica das ciências teóricas como meramente especulativas, sem qualquer finalidade que as transcendesse, lançaram algumas importantes bases da ciência moderna, provocando revisões sobre a natureza dessas ciências e da relação teoria-prática. Bacon postulou que as ciências teóricas deveriam ter como finalidade a produção de conhecimentos necessários para propiciar o controle da natureza. O positivismo de Comte (1798-1857) radicaliza o ideal baconiano e transforma as ciências naturais em únicas referências válidas de conhecimento científico, negando às artes, saberes de natureza técnica, o status de ciência. A partir de então, a noção de prática foi reformulada e, afastando-se da concepção aristotélica, tornouse objeto de outro tipo de ciência definida em estreita relação de dependência com a ciência teórica: a ciência aplicada. A esta caberia a função de transferir para os contextos da vida prática os conhecimentos das ciências teóricas.

Todavia, como bem assinala Santos (2017), as ciências aplicadas passaram a conceber a prática como um objeto teórico que deveria ser explicado pelos saberes das ciências puras, ignorando a dimensão do saber-fazer. Diante disso, torna-se necessário reconhecer duas acepções para a noção de prática:

[..] podemos distinguir um primeiro sentido da prática, entendida como uma atividade compreensiva, cujo objetivo seria fornecer as bases teóricas que devem guiar a ação em determinado contexto. Nessa perspectiva, a prática propriamente dita não existe, mas espera-se que ela resulte da transposição do conhecimento teórico, do contexto de produção para o de aplicação, mantendo-se essencialmente inalterado. Numa segunda acepção, podemos definir a prática como a competência técnica necessária para o exercício de determinada tarefa, oficio ou profissão. Nesse caso, o conhecimento teórico, embora importante e indispensável, é insuficiente para garantir a ação humana, que estará sempre sujeita a variações em virtude das contingências e vicissitudes do contexto social. (SANTOS, 2017, p. 154)

No campo da educação, como em outras áreas nas quais as duas concepções de prática precisam ser articuladas ou acionadas simultaneamente, a complexidade do contexto dá origem a objetos de estudo igualmente complexos, dificilmente passíveis de uma abordagem monodisciplinar. A prática educativa compõe-se de aspectos filosóficos, sociológicos, psicológicos, antropológicos, pedagógicos e didáticos, tomados como objetos de diferentes disciplinas que compõem as ciências da educação. Embora cada uma delas se caracterize como interdisciplinar, dado que sua composição engloba aspectos teóricos e/ou metodológicos de uma disciplina específica (sociologia, filosofia, psicologia etc.) articulados a fatores próprios do contexto educacional, é preciso cuidar para que haja uma integração entre todas elas na prática educativa, entendida como atividade situada que envolve objetivos e atores específicos. Essa tarefa integradora compete à didática geral e às didáticas específicas das disciplinas.

Não podemos deixar de reconhecer que a distinção entre essas duas esferas da didática reflete a lógica da fragmentação e da hiperespecialização do saber característica da ciência moderna, tal como ela se configurou a partir do século XIX. Na Didática Magna de Comenius (1592-1670), primeira obra do gênero, era inconcebível pensar na arte de ensinar de maneira fragmentada a ponto de se imaginar a necessidade de uma teoria geral do ensino e uma específica de cada disciplina. Comenius, como era próprio de seu tempo, concebia a didática de maneira holística, conforme fica evidente em sua apresentação da obra aos leitores:

Nós ousamos prometer uma Didática Magna, ou seja, uma arte universal de ensinar tudo a todos: de ensinar de modo certo, para obter resultados; de ensinar de modo fácil, portanto sem que docentes e discentes se molestem ou enfadem, mas, ao contrário, tenham grande alegria; de ensinar de modo sólido, não superficialmente, de qualquer maneira, mas para conduzir à verdadeira cultura, aos bons costumes, a uma piedade mais profunda. (COMENIUS, 2006, p. 13, grifos meus)

O atual estágio da fragmentação e especialização do saber, mesmo num momento em que a ciência moderna é alvo de muitas críticas, aliado ao modo como se dá a divisão institucional do trabalho acadêmico, dificulta consideravelmente ou impossibilita a elaboração de uma didática totalizante nos moldes da obra de Comenius. Na configuração científico-acadêmica vigente, a didática 
geral está circunscrita ao domínio da pedagogia ou das ciências da educação, cabendo às ciências particulares as discussões sobre o ensino de seus respectivos objetos teóricos na educação básica. Diante disso, considerando o escopo deste texto, torna-se necessário investigar como se constituem a didática geral e a didática específica da língua para traçar as conexões entre ambas que vão permitir a elaboração de uma teoria global do ensino de língua portuguesa.

Libâneo (2013, p. 13) define a didática geral como "[...] uma disciplina que estuda os objetivos, os conteúdos, os meios e as condições do processo de ensino tendo em vista as finalidades educacionais". Na realidade, essa definição pode ser considerada exageradamente ampla se for atribuída à didática geral a tarefa de estudar, em seus pormenores, todos os elementos constitutivos das disciplinas particulares. Contudo, a julgar pelo tratamento que o autor dá ao tema no transcorrer da obra, pode-se concluir que não compete à didática geral estabelecer, por exemplo, os conteúdos de todas as disciplinas escolares, mas fixar os parâmetros que cada uma delas deve observar para defini-los. O mesmo deve acontecer com relação aos demais elementos que compõem o ensino.

Duas tendências caracterizam a produção teórica na didática geral. A primeira ocupa-se do delineamento do contorno geral da disciplina, contemplando os objetivos da educação e suas relações com concepções de ensino-aprendizagem, conteúdos, metodologias de ensino, gestão de sala de aula, concepções de avaliação e formação de professores, considerando as políticas educacionais. São exemplos dessa tendência os trabalhos de Zabala (1998), Pozo (2002), Gimeno Sacristán e Pérez Gómez (1998), Libâneo (2013), dentre outros. A segunda tendência recobre um conjunto de trabalhos que tomam cada componente do ensino como objeto particular de teorização e investigação. Dentre eles, podemos citar: Dolz e Ollagnier (2004), Zabala e Arnau (2010), Gimeno Sacristán et al. (2011) e Perrenoud (2013), que focalizam os objetivos da educação; Coll et al. (2000), que se voltam para uma teoria dos conteúdos do ensino; Perrenoud (2000; 2001), Zabala (2002), Perraudeau (2009), Vianin (2013), Hartman (2015), Cohen e Lotan (2017), que refletem sobre os aspectos metodológicos do ensino; Weinstein e Novodvorsky (2015), que teorizam sobre a gestão da sala de aula; Perrenoud (1999), Hadji (2001) e Luckesi (2011), que se debruçam sobre a avaliação; García (1999), Altet (2000), Paquay et al. (2001), Perrenoud (2002), Tardif e Lessard (2014), que se voltam para a formação profissional de professores.

Como uma ciência da prática educativa, a didática implode a cisão entre ciências de base e ciências aplicadas que se instaurou a partir da perspectiva hegemônica de relação com o saber representada pela ciência moderna. Consequentemente, abrem-se novas possibilidades para se refletir sobre as relações entre teoria e prática, sobretudo quando se abandona o ideal de superioridade da teoria apriorística, apresentada como necessária e suficiente para explicar e resolver todos os problemas práticos, independentemente das contingências e vicissitudes dos contextos em que se desenvolvem as ações humanas, em especial as educativas. Com isso, a noção de prática recupera o sentido aristotélico, configurando-se como um fenômeno, ao mesmo tempo, epistemológico, axiológico e praxiológico.

Lidar com um fenômeno tão complexo quanto a prática educativa obriga os teóricos da didática a transitar por campos de saberes institucionalizados muito diversificados, sem abandonar o necessário conhecimento das representações sociais sobre a educação e seu papel na socialização dos indivíduos, das políticas educacionais, das formas de organização e funcionamento dos sistemas educacionais e das escolas. Essa profusão de fatores, ao mesmo tempo em que torna a didática uma ciência que exige engajamento científico e político, gera, inevitavelmente, visões divergentes sobre os sentidos do processo educativo e os meios mais adequados para se atingirem seus fins. No entanto, o fato de a didática ser um espaço de produção teórica sobre o ensino não lhe confere a prerrogativa, ipso facto, de determinar suas finalidades ou como este deve-se dar, até porque não caberia aos próprios teóricos a tarefa de determinar quais, dentre as várias concepções sobre cada elemento ligado ao ensino, deveriam ser escolhidas. Essa tarefa compete aos gestores das políticas educacionais. Nesse contexto, compete à didática, geral ou específica, a tarefa de acompanhar, auxiliar e avaliar a elaboração dessas políticas, transformando-as em objetos de investigação e reflexão para contribuir com seu aperfeiçoamento.

Para cumprir adequadamente suas funções teóricas e políticas em cenários sociais que estão sempre se transformando, a didática deve voltar-se para a tarefa de questionar constantemente a si própria, as políticas educacionais e as práticas educativas. Questões como as seguintes precisam de respostas sempre atualizadas em função dos avanços das pesquisas, das (necessidades de) mudanças 
sociais e das políticas educacionais: quais devem ser os objetivos da educação? Quais saberes e métodos de ensino são necessários para alcançá-los? Como avaliar a aprendizagem? Como formar professores para garantir o sucesso da educação?

No atual modelo de políticas educacionais globalizadas, a noção de desenvolvimento de competências se erigiu como o objetivo precípuo dos processos formais de educação no Ocidente. Essa orientação se inspirou na observação das novas demandas do mundo do trabalho, que, em face das transformações sociais e tecnológicas contemporâneas, passaram a exigir dos profissionais, além dos saberes de natureza técnica, competências pessoais, interpessoais e sociais. As competências, nesse contexto, são entendidas como saberes práticos ou capacidades de nível superior por meio dos quais o sujeito, como diz Perrenoud (2013), mobiliza saberes específicos necessários para a atuação adequada em determinada situação.

Por ter sua origem ligada às necessidades do mundo do trabalho, a noção de competência tem sido alvo de críticas segundo as quais sua adoção pelas políticas públicas como conceito nuclear para a definição dos objetivos educacionais representaria uma subserviência da escola à economia de mercado ou ainda que a prática educativa se tornaria primordialmente tecnicista. Essas questões têm ensejado muitas controvérsias entre vários teóricos, dentre os quais Dolz e Ollagnier (2004), Bronckart e Dolz (2004), Gimeno Sacristán (2011), Pérez Gómez (2011), Rodríguez (2011), Santomé (2011) e Méndez (2011). Esses autores refletem sobre problemas relativos ao estatuto epistemológico da noção de competências e problematizam os impactos que elas podem provocar no ensino. Essas reflexões giram em torno de questões como as seguintes: como definir as competências? Como estabelecer a relação entre competências profissionais e educacionais? Como definir as competências educacionais e quais critérios devem ser utilizados para selecionar aquelas que devem figurar nos currículos? É realmente necessário que o desenvolvimento de competências seja o objetivo fundamental da educação?

Há ainda outro grupo de estudiosos que, embora não desconheçam as controvérsias em torno das competências, tem optado por um investimento teórico em torno do conceito, com o propósito de torná-lo operacional no campo da didática geral. Autores como Perrenoud (1999, 2013) e Zabala e Arnau (2010, 2016), por exemplo, apresentam concepções teórico-metodológicas para uma didática das competências na qual os saberes disciplinares, interdisciplinares e transdisciplinares são mobilizados para resolver situações-problemas. Esses saberes são divididos em dois tipos principais: os conceituais/factuais das disciplinas específicas, após serem transformados em conhecimentos didáticos, e os transversais, contituídos por: i) temas como gênero, sexualidade, trabalho, consumo, raça, diversidade cultural, meio ambiente etc; ii) habilidades (explicar, descrever, argumentar, comparar, pesquisar, dentre outros) e iii) atitudinais (valores e normas). Os saberes transversais não representam objetos particulares de nenhuma disciplina isoladamente e, por isso, devem permear o conjunto das disciplinas escolares.

Nessa concepção, os conteúdos curriculares são selecionados em função das competências previamente estabelecidas e que representam a finalidade de todo o processo educativo. Essa maneira de conceber os objetivos educacionais resulta em uma nova forma de conceber os conteúdos (COLL et al., 2000), agora subdivididos em factuais/conceituais, voltados para o ensino e a apredizagem de fatos e conceitos disciplinares; procedimentais, voltados para o ensino e a aprendizagem de habilidades transversais, envolvendo os conteúdos conceituais/factuais; atitudinais, também transversais, voltados para o ensino e a aprendizagem de normas, valores e atitudes. Com mudanças tão significativas na concepção dos objetivos e dos objetos de ensino, todos os demais componentes da prática educativa, como a metodologia, a gestão do processo de ensino-aprendizagem e a avaliação, devem ser igualmente reconfigurados. Todos esses aspectos, na medida em que se consubstanciam em novos projetos curriculares, devem conduzir a mudanças nas políticas e práticas de formação de professores.

Essas duas funções da didática apresentadas nos parágrafos anteriores, crítica e epistemológica em torno do conceito de competências, são fundamentais para a caracterização da disciplina como uma ciência da prática que integra, indissociavelmente, fatores epistemológicos, axiológicos e praxiológicos. Além disso, a crítica e a teorização didáticas permitem que essa ciência desempenhe uma função política, informando os gestores das políticas públicas, as universidades, os atores educacionais e a sociedade em geral sobre problemas e possibilidades da utilização de saberes e práticas sociais na elaboração de políticas educacionais. 
Como já foi dito aqui, a fragmentação e a especialização do saber decorrentes da hegemonia do paradigma científico moderno tiveram como uma de suas consequências uma nova forma de divisão e classificação das ciências e do trabalho acadêmico que se refletem também na configuração da didática como disciplina científica. Embora seu modus operandi contrarie vários pressupostos da ciência moderna, sobretudo no que tange às dicotomias ciência pura/ciência aplicada, objetivismo/interpretação e teoria/prática, a institucionalização dos mais diversos campos disciplinares, correlacionada à criação dos cursos de licenciatura e à exigência legal de certificação específica conferida por esses cursos como condição para o exercício da profissão docente nas diferentes áreas de conhecimento, tem colocado alguns desafios para a integração entre a didática geral e a prática de ensino das diferentes disciplinas. O principal desafio a ser superado talvez resida na complexa tarefa de transformar os conhecimentos científicos em objetos didáticos, observando que: i) os objetivos educacionais são diferentes dos objetivos da ciência na relação com o saber; ii) os conteúdos das disciplinas escolares não se identificam, ipsis litteris, com os conhecimentos das disciplinas científicas.

A necessidade de observância a essas duas condições situa a didática geral como espaço de produção teórica responsável por estabelecer os fundamentos e princípios que as didáticas específicas devem observar no processo de construção de objetos de ensino, dentre os quais se situa a transposição didática. Sem essa relação, a didática geral perderia sua razão de ser. De modo análogo, sem a didática geral, as disciplinas particulares não teriam uma referência comum para orientar sua própria constituição como disciplinas escolares, tendo em vista a construção de uma didática global das disciplinas. Essa didática global, diferentemente da didática geral, não tem como finalidade estabelecer os fundamentos teórico-metodológicos que todas as disciplinas curriculares devem observar para se constituírem como componentes da educação básica, mas representa uma ciência particular que, observando os fundamentos da didática geral, estuda e estabelece os elementos que estruturam os processos de ensino-aprendizagem de uma disciplina específica em sua totalidade. Desse modo, o qualificativo "global" se refere ao todo de uma disciplina, enquanto "geral" diz respeito ao que é comum a todas.

No Brasil, a inexistência das didáticas específicas como campos disciplinares institucionalizados tem gerado alguns problemas teóricos e práticos para o ensino, com reflexos na formação de professores e na qualidade da educação básica. Nos cursos de licenciatura, têm prevalecido os modelos acadêmico e tecnicista de formação de professores (SANTOS, 2018), que separa os saberes científicos das disciplinas específicas e os saberes das ciências aplicadas à educação (psicologia, sociologia, antropologia, filosofia e didática geral) em unidades estanques para, em seguida, apresentá-los aos futuros profissionais sem as devidas relações com os objetivos, os objetos de ensino específicos das diferentes disciplinas e seus respectivos processos de ensino-aprendizagem. Sem uma didática global das disciplinas, os cursos de licenciatura funcionam como se os conhecimentos técnicos apresentados de modo fragmentado fossem suficientes para tornar o futuro profissional apto a atuar no contexto escolar, como se houvesse uma identidade entre conhecimentos científicos e conhecimentos didáticos, e como se os futuros professores fossem capazes de, isoladamente, elaborar a síntese necessária entre os saberes disciplinares dispersos e a didática.

No âmbito da educação básica, as instituições governamentais - Ministério da Educação (MEC), Secretarias Estaduais e Municipais de Educação - têm assumido a responsabilidade de elaborar, se não a didática global de cada disciplina, pelo menos um conjunto de parâmetros curriculares globais e, em grande medida, orgânicos, a exemplo dos Parâmetros Curriculares Nacionais (PCN) e da recente Base Nacional Comum Curricular (BNCC), nos quais se integram fundamentos da didática geral e uma seleção de conteúdos das disciplinas específicas, para orientar a elaboração dos currículos e Projetos Político-Pedagógicos nas unidades escolares. Paralelamente a isso, as diretrizes nacionais para a formação de professores enfatizam a necessidade de os cursos de licenciatura observarem essas orientações curriculares oficiais na formação inicial de professores. No entanto, a predominância dos modelos acadêmico e tecnicista de formação profissional, juntamente com a inexistência das didáticas específicas, tem sido um entrave na implementação efetiva dessas políticas educacionais.

\section{A DIDÁTICA DA LÍNGUA COMO DISCIPLINA EMERGENTE}

Na França, o problema da inexistência das didáticas das disciplinas começou a ser enfrentado a partir da década de 1960, com destaque para os trabalhos de Chevallard (1985) sobre a didática da matemática. Seus estudos legaram à didática, dentre outras importantes formulações, dois conceitos fundamentais: a noção de transposição didática, entendida como a passagem do 
conhecimento científico ao conhecimento didático, e a de engenharia didática, designação atribuída à pesquisa das situações didáticas através de modelos experimentais de ensino, com o objetivo de compreender os fatores que interferem no sucesso ou fracasso dos processos de ensino-aprendizagem e intervir sobre a prática educativa para aperfeiçoá-la.

A didática das línguas teve início na década de 1970, em países de língua francesa, inspirada nos trabalhos de Chevallard. Petitjean (2008), contudo, avalia que não é possível adotar o conceito de transposição didática ao ensino de língua de forma tão restrita como indica a concepção de Chevallard por duas razões: i) em matéria de ensino de língua, o objetivo é o desenvolvimento de competências de uso da linguagem e não o ensino de saberes; ii) os conteúdos a serem ensinados não se reduzem aos saberes científicos transpostos, mas devem refratar as práticas sociais de referência que definem as situações didáticas. Nas palavras do autor: "aplicado ao francês, esse conceito [de transposição didática] dá conta de que o fato de falar, ler, escrever, pensar, em graus diversos, são competências que se desenvolvem e se exercem em práticas não escolares" (PETITJEAN, 2008, p. 21).

Da forma como entende o autor, no caso da didática da língua, a construção dos objetos de ensino não se coaduna com uma concepção restrita da transposição didática, uma vez que a aprendizagem dos usos da língua não se limita à aprendizagem de saberes científicos. Para atender os objetivos educacionais, o ensino de língua deve contemplar as práticas sociais de linguagem tomadas como referências para a organização das situações de ensino. Essa concepção ampla da transposição didática, orientada para a didatização das práticas sociais e não apenas dos saberes científicos, torna mais complexas as tarefas da engenharia didática.

Um aspecto que passa a merecer bastante cuidado diz respeito à relação entre as variáveis espaço-tempo das situações didáticas e o desenvolvimento de competências como objetivos centrais do ensino de língua. Afinal, se a produção de qualquer gênero textual, como define Bakhtin (2016), deve observar, em cada contexto comunicativo, o conteúdo temático (as ideias), a forma composicional (a estrutura macro e microtextual) e o estilo (a seleção adequada dos recursos linguísticos), é possível à escola organizar situações didáticas capazes de inserir os estudantes em situações comunicativas reais, contemplando todos esses elementos em cada gênero que seja objeto de processos de ensino-aprendizagem? Isso implicaria a utilização de estratégias pedagógicas que ultrapassassem os limites do espaço e tempo da sala de aula. Ou seriam as práticas sociais de referência apenas modelos para orientar a elaboração de situações didáticas simuladoras das práticas sociais de linguagem no contexto escolar? Se assim for, como assegurar que atividades simuladas, fora do contexto real, possam garantir o efetivo desenvolvimento de competências? Quais critérios utilizar para selecionar os gêneros? Como distribuí-los ao longo dos anos de escolarização e das unidades letivas? Como estabelecer sua progressão?

Outro problema que apresenta dificuldades para a didática da língua com foco no desenvolvimento de competências se refere ao tratamento didático dos recursos estilísticos constitutivos dos diversos gêneros textuais. Boa parte dos gêneros escolarizados, quando em seus contextos reais, é produzida por sujeitos que já passaram pela educação básica e até por cursos de formação específica para habilitá-los a escrever utilizando adequadamente os recursos estilísticos. Como se sabe, a escola estabelece uma progressão dos conteúdos gramaticais, ao longo dos anos de escolarização, de uma maneira que faz os alunos se depararem com as atividades de produção textual bem antes de construírem todos os saberes linguísticos que as atividades de produção dos diversos gêneros textuais demandam. No entanto, se tudo ocorrer conforme consta da estrutura curricular, os estudantes só terão domínio desses conteúdos nos anos finais da formação escolar básica.

Esse conjunto de problemas, dentre outros, evidencia a importância da didática da língua como uma teoria da prática que, articulada à didática geral, deve exercer as funções de crítica dos saberes científicos, das políticas educacionais e do currículo, além da teorização e do exercício da função política através da engenharia didática. Dolz (2016) apresenta uma apropriação do conceito de engenharia didática para o estudo do ensino de língua nos seguintes termos:

A engenharia didática visa a conceber tecnicamente as tarefas e as ações dos alunos para aprender, coordenar as intervenções dos professores e elaborar dispositivos suscetíveis de resolver os problemas de ensino da língua. Ela organiza, transforma e adapta os saberes sobre a língua e as práticas discursivas para o ensino. Principalmente, a engenharia tem a responsabilidade de conceber projetos escolares e de elaborar dispositivos, atividades, exercícios, materiais escolares e novas tecnologias da comunicação escrita, oral e audiovisual. Com esse objetivo, ela imagina e planifica as formas sociais de trabalho escolar dos alunos. Também está encarregada de inventar 
ferramentas para facilitar as aprendizagens e de orientar as intervenções e os gestos profissionais do professor. Finalmente, ela realiza pesquisas sobre as inovações introduzidas, controlando e avaliando a implementação das novidades. (DOLZ, 2016, p. 240-241)

No Brasil, ainda não se pode falar de uma didática do português como disciplina ou área de investigação institucionalizada. Sendo assim, as questões que envolvem o ensino de língua vêm recebendo tratamento fragmentário no âmbito da linguística aplicada e mesmo da LA, contemplando, em geral, os objetos de ensino ou sugestões metodológicas, sem a devida fundamentação didática e o desenvolvimento de pesquisas empíricas para avaliar a pertinência das propostas. É importante, no entanto, distinguir a forma como as duas modalidades da linguística como ciência aplicada têm lidado com o ensino para que possamos compreeender a urgência de uma didática da língua portuguesa no Brasil.

A LA se autodenomina um campo disciplinar institucionalmente constituído de investigação sobre problemas que envolvem o uso da língua em contextos reais. Nessa acepção, as questões ligadas ao ensino se referem a temas que estão, em geral, além do escopo das disciplinas da linguística pura, tais como os (multi)letramentos (ROJO, 2009; ROJO, MOURA, 2012; BUNZEN, MENDONÇA, 2006, 2013). Não obstante, há autores que se definem como linguistas aplicados, em sentido restrito, que vinculam suas discussões sobre o ensino de gramática, por exemplo, a uma abordagem alinhada ao modelo aplicacionista, de maneira total ou parcial. Incluem-se nessa perspectiva trabalhos como os de Travaglia (2009) e Antunes (2007, 2009, 2014), que buscam transferir construtos teóricos da linguística pura ao ensino. Nesses casos, diante da falta de teorização sobre a gramática no campo da LA, a prática usual, quando a discussão sobre gramática se torna necessária, tem sido recorrer aos construtos teóricos da linguística pura ou a outras disciplinas da linguística aplicada, como a linguística textual. Nesses casos, ainda que consigam ir além do mero aplicacionismo, as propostas pedagógicas não são capazes de superar os problemas comuns a qualquer tentativa de transferência de conhecimentos científicos ao ensino de língua sem a devida observância aos princípios da didática.

A linguística aplicada, por sua vez, representa a contraparte da linguística teórica, cujos conhecimentos busca transferir para o ensino. Trata-se de um conjunto disperso de proposições motivadas pelo ideal de transferência para o ensino de objetos teóricos das diferentes disciplinas da linguística, de maneira monodisciplinar, sem considerar as possíveis articulações dessas disciplinas entre si e com os objetivos da educação, além de não observarem os pressupostos da didática. Na próxima seção, apresentarei alguns aspectos dessa perspectiva e farei análises de como se dá a construção da gramática como objeto de ensino.

As duas perspectivas de linguística aplicada têm em comum o fato de não representarem corpos coesos de produção teórica que encontram na didática geral e na didática da língua as referências teórico-metodológicas para a construção de objetos de ensino e de pesquisa sobre os processos de ensino-aprendizagem da língua. Nesses trabalhos, não se verificam discussões sobre as competências como definidoras dos objetivos educacionais, apesar de nossas orientações curriculares oficiais, PCN e BNCC, se alinharem a essa perspectiva; não há menção explícita aos conteúdos conceituais, procedimentais e atitudinais como recursos para o desenvolvimento de competências; não se mencionam as concepções de ensino-aprendizagem que fundamentam as propostas apresentadas. Sem a explicitação desses elementos, a avaliação das metodologias sugeridas fica comprometida. Para completar, não há discussões sobre as concepções de avaliação da aprendizagem - diagnóstica, somativa, processual e formativa.

\section{LINGUÍSTICA APLICADA E ENSINO DE GRAMÁTICA}

O lugar e o sentido da gramática no ensino de português são objetos de controvérsias no âmbito da linguística aplicada e resultam de uma crítica epistemológica à teoria da chamada gramática tradicional. Tais críticas geraram um conjunto de problemas pedagógicos em torno de questões como qual gramática ensinar, por que e como ensiná-la. É possível relacionar as motivações dessas críticas pedagógicas ao fato de as políticas educacionais atribuírem às Instituições de Ensino Superior (IES) a responsabilidade pela formação inicial dos professores da educação básica. No Brasil, a exigência da formação universitária para o exercício da docência obriga os professores acadêmicos a refletir sobre o ensino, o que costuma acontecer sob a égide do conhecimento científico produzido no ensino superior. Esses saberes têm orientado a configuração dos currículos dos cursos de formação dos futuros profissionais, colocando-os em contato com as críticas epistemológica e pedagógica dirigidas à gramática tradicional. 
O que chamei de crítica epistemológica da gramática tradicional, porém, não consiste num discurso unívoco. Ao contrário, fundase num pluralismo teórico baseado nos paradigmas funcionalista, formalista e sociolinguístico, os quais têm em comum a utilização de metodologias descritivistas. Esse pluralismo, salutar no âmbito da ciência pura por tornar possível a realização de estudos da linguagem sob diferentes perspectivas, gera alguns impasses para a ciência aplicada. Um deles diz respeito à polissemia em torno do conceito de gramática, vista com naturalidade no contexto científico em função das diferentes perspectivas teóricas que orientam os estudos linguísticos, mas que se revela bastante problemática quando transferida para o contexto escolar, onde essas concepções se somam aos sentidos sociopolíticos historicamente associados à gramática tradicional/normativa.

Outro problema conceitual tem relação com a terminologia a ser adotada no ensino. Atualmente, as gramáticas normativas, em geral, tomam como referência a Nomenclatura Gramatical Brasileira (NGB), criada no final da década de 1950 com o intuito de padronizar a terminologia adotada em situações de ensino e de outras práticas sociais que exigem o conhecimento da língua padrão. Por estar comprometida com a ciência pura, a linguística aplicada, preservando o princípio da fragmentação e especialização do saber, transfere às suas propostas para o ensino de língua o pluralismo terminológico e conceitual dos diversos programas de estudos científicos da língua.

Desse modo, faz-se necessária uma reflexão crítica, à luz dos fundamentos da didática geral e da língua, sobre as teorias gramaticais na linguística pura e suas relações com a gramática normativa, cotejando suas articulações educacionais e sociopolíticas. Trata-se de um exercício das funções crítica, teórica e política da didática da língua, bastante necessário no contexto brasileiro, onde boa parte do debate sobre o ensino de língua portuguesa e os cursos de licenciatura em letras são orientados pelos saberes da linguística aplicada.

\subsection{A GRAMÁTICA NA LINGUÍSTICA PURA}

A linguística deve seu status de ciência ao trabalho de Ferdinand Saussure, que encontrou no estruturalismo uma forma de conferir ao estudo da língua rigor científico equivalente ao das ciências naturais. Tomando como modelo de cientificidade o objetivismo positivista, Saussure (2004) distinguiu a linguística interna da externa, reconhecendo apenas a primeira como digna de ser chamada de ciência. Com isso, buscava definir a língua como um objeto puro: "[...] nossa definição de língua supõe que eliminemos dela tudo o que lhe seja estranho ao organismo, ao seu sistema, numa palavra: tudo que se designa pelo termo "linguística externa"” (SAUSSURE, 2004, p. 29). Um pouco adiante, Saussure postula a natureza psicológica da língua: "[...] o objeto concreto de nosso estudo é, pois, o produto social depositado no cérebro de cada um, isto é, a língua” (2004, p. 33). Para complementar a caracterização da língua como objeto de estudo da linguística interna, diz ainda: “[...] a língua é um sistema que conhece apenas sua ordem própria” (SAUSSURE, 2004, p. 33).

A linguística externa, por sua vez, ocupar-se-ia dos fatores sócio-antropológicos da língua relacionados com os aspectos práticos do funcionamento social da língua em torno de questões como civilização, nacionalismo, escrita e dialetação. Saussure não nega que esses fatores afetam a língua de variadas maneiras, mas entende que isso não anula a possibilidade de se estudá-la como um objeto puro. Ademais, a distinção entre linguística interna e externa impõe a Saussure a necessidade de explicar as relações de convergência e divergência entre as noções de língua, fala - fenômenos naturais - e escrita - produto cultural.

Para Saussure, a escrita é estranha ao sistema interno: "Língua e escrita são dois sistemas distintos de signos" (2004, p. 34). Dessa forma, ele conclui, acertadamente, que mudanças ou alterações sofridas por um desses sistemas não necessariamente afeta o outro. O mesmo não se dá em relação à fala, que se implica mutuamente com a língua: “[...] a língua é necessária para que a fala seja inteligível e produza todos os seus efeitos; mas esta é necessária para que a língua se estabeleça” (SAUSSURE, 2004, p. 27). Com esses postulados, Saussure lançou as bases da linguística como ciência pura e descritiva que vigoram até os dias atuais. Como ciência descritiva, a linguística se interessa pela língua como ela é e não pelo que ela deveria ser, como faz a gramática normativa. A investigação científica, então, busca descrever e explicar as regras de funcionamento da língua que são inerentes ao sistema, excluindo as regras oriundas de valores ou normas socioculturais, como ocorre com a escrita, que é indissociável desses valores e normas. 
O estruturalismo saussuriano inaugurou não apenas uma nova metodologia de estudo da língua, o descritivismo, como também abriu caminhos para novas concepções de gramática:

\footnotetext{
Devemos distinguir cuidadosamente gramática, enquanto estrutura mental postulada, da gramática do linguista, uma teoria explicitamente estruturada que visa exprimir de forma precisa as regras e princípios da gramática existente na mente do falante-ouvinte ideal. A gramática do linguista é uma teoria científica, correta na medida em que corresponde à gramática internamente representada. [...] É comum empregar o termo "gramática" com ambiguidade sistemática, de modo que o contexto determine se estamos nos referindo à gramática internalizada ou à teoria do linguista. (CHOMSKY, 1981, p. 166)
}

É curioso que a linguística se utilize do termo gramática para se referir à estrutura mental que torna a faculdade humana da linguagem possível (gramática internalizada) e ao trabalho de descrição dessa estrutura pelos linguistas (gramática descritiva), porque, etimologicamente, a palavra gramática, grammata, que significa "letra", está diretamente ligada às práticas de leitura e escrita. Na linguística gerativa de Chomsky, a gramática mental, em seu estágio inicial, se apresenta como uma estrutura potencial que permite ao sujeito aprender qualquer língua, desde que seja exposto a ela. Uma vez adquirida pelo menos uma língua, a gramática universal se converte na gramática internalizada dessa língua. Para estudar essa gramática, o linguista desenvolve uma teoria científica chamada gramática descritiva.

O desenvolvimento histórico e epistemológico da linguística faria surgir novas disciplinas em seu interior, que acabaram por transformá-la numa grande área com diversas disciplinas que tomam como objetos diferentes aspectos da linguagem. A sociolinguística, por exemplo, surgiu com o objetivo de explicar a mudança linguística (WEINREICH; LABOV; HERZOG, 2006). Dois problemas foram fundamentais para seu surgimento: i) se a língua é um sistema que só conhece sua ordem própria e homogêneo, como explicar o fato de que todas as línguas mudam?; ii) assumido o pressuposto de que as línguas não mudam abruptamente, mas de maneira gradativa ao longo do tempo e em diferentes níveis estruturais (fonológico, morfológico, sintático e semântico), como explicar que elas continuem funcionais enquanto mudam?

Para responder a essas questões, Labov (2008) postulou a necessidade de se adotar uma metodologia de estudo da língua que relacionasse estrutura linguística e estrutura social. Com esse procedimento, ele reafirmaria a tese saussuriana de que a língua é um produto social depositado no cérebro humano, acrescentando que as estruturas causadoras da diferenciação social (classes sociais, idade, sexo, raça etc.) também causam diferenciação ou variação na língua. Três conclusões derivam dessas premissas: i) existe uma relação causal entre diferenciação social e variação linguística, de maneira que não é possível explicar as regras de funcionamento da língua unicamente pela descrição de sua ordem interna; ii) a ordem da língua não deve ser identificada com homogeneidade, o que resulta na concepção de língua como sistema heterogêneo e ordenado; iii) a mudança linguística se caracteriza por uma relação causal decorrente da interação entre diferenciação social e variação linguística.

Apesar das diferenças entre o estruturalismo de Saussure e o estrutural-funcionalismo de Labov, dois pontos definidores da linguística como ciência pura permanecem comuns a ambos: a concepção de língua como uma estrutura mental e a ideia da implicação mútua entre língua e fala, com exclusão da escrita.

\subsection{A LINGUÍSTICA COMO CIÊNCIA APLICADA AO ENSINO DE GRAMÁTICA}

Na seção anterior, caracterizei, em linhas gerais, a linguística como uma ciência alinhada ao paradigma positivista, como uma ciência pura que isola seu objeto de qualquer influência subjetiva, axiológica ou praxiológica. A partir da definição de língua como um produto mental inato, homogêneo ou heterogêneo, a linguística contribuiu para que língua e gramática se tornassem noções polissêmicas também nos processos de construção de objetos de ensino elaborados pela linguística aplicada lato ou stricto sensu. 
Se considerarmos apenas as regras da racionalidade científica que orientam a produção do conhecimento na linguística teórica, concluiremos que seu modus operandi está bastante coerente com os procedimentos normais da prática científica moderna. Os problemas surgem quando se pretende transferir os conhecimentos científicos produzidos segundo as regras próprias desse contexto para outros que seguem regras diferentes de constituição e funcionamento, por meio de uma relação vertical baseada na pressuposição da superioridade da ciência, sem considerar os aspectos específicos que regulam as relações com o saber nos contextos-alvo, a exemplo do ensino de língua nas instituições de educação formal.

O foco na abordagem normativa tem sido o principal alvo das críticas da linguística aplicada ao ensino de gramática. Tomando como referência a concepção de língua como objeto puro, produto mental depositado no cérebro dos falantes e as pesquisas sociolinguísticas, os linguistas aplicados têm postulado que o ensino adote uma abordagem descritiva. Ou seja, a língua deve ser estudada como ela é e não como deveria ser. Essa mudança de paradigma redefine os objetivos do ensino de gramática, defendendo o abandono da teoria gramatical tradicional, de boa parte de seu aparato conceitual e terminológico e sua metodologia de ensino. Consequentemente, caberia aos linguistas aplicados construir novos objetos de ensino, novas metodologias e estratégias de avaliação, bem como produzir gramáticas pedagógicas e materiais didáticos em conformidade com a abordagem descritivista.

Relembrando: o descritivismo fundamenta-se em alguns princípios básicos estabelecidos por Saussure: língua e fala se implicam mutuamente, mas a escrita é um sistema semiótico diferente, sem relação de implicação com os anteriores. Esse, porém, é um postulado problemático para os linguistas aplicados, pois um ensino de gramática orientado pela perspectiva científica deveria ignorar a escrita, algo absolutamente inconcebível numa sociedade letrada como a nossa. Sendo assim, como os linguistas aplicados têm lidado com os problemas decorrentes do ideal de orientar o ensino de gramática e, consequentemente, a escrita por uma perspectiva científica naturalista, que tem a fala como seu objeto de estudo?

Perini (2010, p. 18), por exemplo, considera que "[...] a gramática é uma disciplina científica, tal como a astronomia, a química, a história ou a geografia; ela deve ser estudada porque é parte da formação cientifica dos alunos”. E afirma sua inutilidade prática: “[...] estudar gramática não leva, nunca levou, ninguém a desenvolver suas habilidades de leitura e escrita ou fala, nem sequer seu conhecimento prático do português padrão escrito" (PERINI, 2010, p. 18). No entanto, apesar de sua gramática propor uma descrição do português falado no Brasil, mesmo sem apresentar um corpus de língua falada para as tarefas de análise, o autor faz inúmeras críticas à gramática normativa, que, como sabemos, tem como objeto de descrição e normatização a língua padrão escrita.

A Pequena gramática do Português brasileiro, de Castilho e Elias (2012), é definida como descritiva e pedagógica. Os autores elegem como objetivo do ensino de gramática a descrição do português brasileiro como língua natural:

[...] como vamos ensinar uma língua que os falantes já conhecem bem, pelo menos na modalidade oral? O fato é que não vamos ensinar essa língua do mesmo modo como ensinaríamos uma língua estrangeira. O que faremos édesvendar o conhecimento que temos sobre ela, conhecimento que está guardado em nossas mentes. O trabalho do professor de português é caminhar junto com os alunos nesse processo de descobertas. (CASTILHO; ELIAS, 2012 , p. 14, grifos meus)

O propósito de descrever a língua como um produto mental aproxima as duas obras mencionadas. Contudo, diferentemente de Perini, Castilho e Elias não excluem completamente as possibilidades de os estudos em gramática descritiva contribuírem para a aprendizagem da escrita:

É evidente que podemos e devemos ensinar a modalidade escrita, e também como se deve manejar o idioma em sua modalidade culta, padrão. Essa é a língua do Estado, de que devemos nos apropriar, pois ela promove socialmente seus usuários. Não deixamos isso de lado, pelo contrário: estamos convencidos de que a reflexão sobre a língua abre um caminho de maior eficácia nessa direção. (CASTILHO; ELIAS, 2012, p. 14).

Apesar dessa declaração de intenção, a metodologia para o estudo da língua apresentada pelos autores deixa claro que os estudos gramaticais têm como fim explícito a descrição da língua como objeto científico. Castilho e Elias (2012, p. 45-46) apresentam uma metodologia de pesquisa a ser adotada nos estudos gramaticais na escola, com os seguintes passos: 
i. Coleta de material de estudo: conversas gravadas e textos escritos variados;

ii. Hipóteses de trabalho: no estudo das línguas, as hipóteses criam o objeto científico;

iii. Unidades de análise: fonema, morfema, palavra, sintagma, sentença e texto;

iv. Transcrição: no caso de conversas gravadas;

v. Redação do trabalho de análise: relato dos projetos de pesquisa.

As propostas desses autores para o tratamento da gramática na escola, filiadas aos paradigmas sociolinguístico, formalista e/ou funcionalista de estudos da língua, substituem a ideia de ensino pela de estudo, reafirmando a tese de que os falantes, por já conhecerem a língua, não precisam aprendê-la e sim estudá-la. Dessa forma, ratificam a concepção de língua como uma estrutura mental que possui regras naturais de funcionamento, cabendo ao professor auxiliar os alunos na tarefa de explicitá-las através da utilização do método científico. Essa perspectiva vai ao encontro da afirmação de Castilho e Elias, segundo a qual a reflexão sobre a língua acarreta melhorias na aprendizagem da escrita padrão, uma vez que, por não ser natural, a escrita precisa ser sistematicamente ensinada.

Essas contradições evidenciam diferenças entre os objetivos da ciência e os objetivos da educação, caracterizando uma concepção teórico-metodológica de tratamento escolar da gramática que chamarei de descritivismo puro. Nessa acepção, busca-se manter a pureza da língua, tal qual definida pela linguística teórica, através da adaptação da metodologia científica ao contexto escolar, excluindo-se de seu escopo o ensino sistemático da escrita padrão.

Existe, porém, outro tipo de descritivismo entre os linguistas aplicados: o relativista. Trata-se de uma abordagem mais claramente associada ao paradigma sociolinguístico, que concebe a padronização linguística não como um processo neutro de uniformização linguística, mas como uma questão que reflete e refrata uma série de problemas ligados à dominação e à exclusão social. Segundo essa perspectiva, a norma padrão representaria um ideal linguístico artificial que não corresponde aos usos reais das pessoas mais escolarizadas, definidas como falantes cultos da língua, de acordo com os critérios estabelecidos pelo Projeto de Estudos da Norma Urbana Culta falada no Brasil (NURC). A esses usos reais da língua por pessoas com nível superior completo os linguistas atribuíram a designação de normas cultas, expressas no plural por serem heterogêneas.

Paradoxalmente, o descritivismo relativista é uma linguística da norma que, mesmo assumindo posições normativas acerca de como a sociedade deve relacionar-se com a língua, recusa a normatização linguística fundada em critérios sociais. Os resultados de pesquisas variacionistas sobre a fala dita culta são utilizados como fundamentos para a tese de que o ensino do padrão escrito idealizado deve ser substituído por uma pedagogia da variação linguística (ZILLES; FARACO, 2015), uma concepção controversa acerca do estudo da língua, porque, ao mesmo tempo em que estabelece que as normas cultas devem ser os objetos de ensino, não se assume normativa. Com efeito, se é natural aos falantes cultos utilizarem as normas cultas, o mesmo não se pode dizer dos demais falantes do português, que deverão aprender essas normas através da escola. Logo, a seleção de uma norma como objeto de ensino, por qualquer ângulo, será sempre uma ação normativa.

É preciso observar ainda que as pesquisas sociolinguísticas sobre as normas cultas desconsideram a história dos falantes cultos, que passaram por longos períodos de estudos sistemáticos da norma padrão. Ou seja, é preciso não ignorar que o falante culto só fala da forma verificada nas pesquisas porque estudou a norma padrão, ainda que se desvie dela em alguns aspectos, sobretudo na língua falada. Desse modo, aceitar que um falante só é considerado culto após finalizar o período de educação superior, implica reconhecer que sua fala é resultante de processos sistemáticos de ensino normativo.

Dois fatores impedem os linguistas relativistas de se assumirem normativistas: a obediência irrestrita aos princípios da linguística teórica, que se assume como ciência descritiva, e a impossibilidade de se determinar um padrão culto unificado como referência para o ensino, dado que as normas cultas são heterogêneas. Diante disso, só resta aos linguistas assumirem o relativismo normativo, classificado de duas formas por Boudon: 
O bom relativismo atraiu a atenção para o fato de que as representações, as normas e os valores variarem segundo os meios sociais, as culturas e as épocas. O relativismo ruim concluiu disso que as representações, as normas e os valores são destituídos de fundamento: que são construções humanas inspiradas pelo meio, pelo espírito do tempo, por paixões, interesses ou instintos. Atribuir uma objetividade às representações, aos valores e às normas seria sempre uma ilusão. (BOUDON, 2010, p. 7, grifos do autor)

De acordo com Boudon, o bom relativismo reconhece a necessidade das normas sociais, enquanto o ruim as nega. O descritivismo relativista rejeita a norma padrão, que é social, por considerá-la ideal, em favor das normas cultas, entendidas como os usos reais, naturais, da língua. Ao recusar o reconhecimento da língua padrão como uma norma socialmente legítima, o descritivismo relativista é atravessado por um paradoxo: defende a necessidade de substituição da norma padrão pelas normas cultas no ensino, um gesto inegavelmente interventivo, mas rejeita a possibilidade de intervenção social na língua com o propósito de padronizar seu uso em situações específicas, porque, se isso ocorrer, haverá uma interferência na natureza da língua. Esse fato chama a atenção para a distinção entre normas orgânicas ou biológicas e normas sociais, conforme a formulação de Canguilhem (2009, p. 119): "[...] se as normas sociais pudessem ser percebidas tão claramente quanto as normas orgânicas, seria loucura dos homens não se conformarem a elas. Como os homens não são loucos e como não existem sábios, segue-se que as normas sociais têm de ser inventadas e não observadas".

A julgar pelas palavras de Canguilhem, se os linguistas não admitem a possibilidade de se intervir sobre a língua para normatizá-la, é porque a concebem como um organismo natural, que segue regras próprias, cabendo ao pesquisador apenas as tarefas de observação e descrição de seu funcionamento. Essa recusa em aceitar a língua como um fenômeno sujeito a processos de normatização baseados em valores sociais evidencia a vinculação do descritivismo relativista à linguística teórica - busca-se transferir para a escrita as conclusões de estudos sobre a fala, ignorando-se a incomensurabilidade entre esses diferentes sistemas semióticos - e ao relativismo ruim, quando se assume que as representações, normas e valores sociais não têm fundamento válido. Mesmo sem resolver seu paradoxo, o descritivismo relativista segue firme em sua concepção de estudo/ensino da língua orientada para a descrição variacionista. Trabalhos como os escritos ou organizados por Bagno (2001, 2010), Mattos e Silva (2004, 2005), Vieira e Brandão (2007), Faraco (2008), Bortoni-Ricardo et al. (2014), Martins, Vieira e Tavares (2014), Zilles e Faraco (2015) apresentam propostas teórico-metodológicas para um ensino variacionista acerca de tópicos gramaticais como concordância, regência, colocação pronominal, estratégias de relativização, dentre outros, nas quais predominam análises da língua falada, segundo princípios da pesquisa sociolinguística aplicada ao contexto escolar.

Em geral, para promover o desenvolvimento das habilidades de leitura e escrita, os descritivistas propõem que os estudos gramaticais sejam complementados com atividades de leitura e produção textual de gêneros diversos. Essa orientação, ao separar em blocos estanques o estudo da gramática, por um lado, e o desenvolvimento de habilidades de leitura e escrita, por outro, deixa uma questão sem resposta: qual a finalidade de se estudar a gramática descritiva se os alunos podem aprender a ler e escrever por meio do trabalho exclusivo com os gêneros? O estudo da gramática não seria um fim em si mesmo, algo que já acontece com a tão criticada metodologia de ensino da gramática normativa?

O descritivismo relativista apresenta ainda outro paradoxo. As críticas à hegemonia socioeducacional da norma padrão se devem, em grande medida, aos valores sociais a ela atribuídos, os quais, assumindo-se uma compreensão da estrutura social como dividida em classes dominantes e classes dominadas, representariam a ideologia das classes com mais acesso aos bens culturais, econômicos e educacionais. A ideia de substituir a norma padrão pelas normas cultas como referências para o ensino e o uso da língua invalida toda a crítica social utilizada para se rejeitar a primeira, uma vez que as normas cultas são forjadas segundo os mesmos critérios da norma padrão, considerada elitista e excludente. Afinal, não seriam os membros das classes dominantes todos falantes cultos, de acordo com os critérios estabelecidos pela sociolinguística brasileira?

A compreensão desse paradoxo levou Bagno (2017), que até então vinha defendendo o descritivismo relativista (BAGNO, 2003, 2010), à seguinte constatação: 
Se a norma-padrão tradicional exclui, na prática, todas as classes sociais - por não se basear em nenhuma variedade linguística autêntica -, a "norma culta real", por sua vez, excluiria todas as camadas menos letradas, que correspondem a nada menos do que 75\% da população brasileira, quase 150 milhões de indivíduos classificados como analfabetos funcionais.

A impossibilidade de "ensinar a norma culta" se dá também pelo fato, reconhecido pelo mesmo Faraco (2016, p. 267) de que ela é um "peixe ensaboado: cada vez que achamos que a temos bem segura na mão, ela nos escapa. (BAGNO, 2017, p. 104, grifos e aspas do autor).

Diante disso, o autor conclui:

[...] querer instituir como objeto de ensino a "norma culta real" em lugar do padrão tradicional é um empreendimento extremamente difícil [...].

Diante disso, talvez seja menos utópico postular, para o ensino, o letramento contínuo e ininterrupto dos aprendizes. O contato frequente com a escrita, a prática constante da leitura e da reflexão sobre a língua (reflexão que inclui, também, o debate sobre a variação e a mudança e os valores atribuídos a ela) levam, inevitavelmente, a que a pessoa, no processo educacional, se conscientize da existência de incontáveis gêneros textuais, que se manifestam segundo normas múltiplas de configuração do discurso, normas e gêneros sincronicamente variáveis e que se transformam diacronicamente [...]. (BAGNO, 2017, p. 106-107, grifos e aspas do autor)

De fato, se as coisas se dão conforme a análise social dos linguistas, seria muito ingênuo acreditar que a classe social detentora do poder abriria mão da norma linguística que utiliza como um de seus mecanismos de poder. A norma culta, portanto, não representa uma proposta viável de solução para o problema da dominação ideológica e socioeconômica pelas classes dominantes. Para resolver esse paradoxo no ensino de língua, Bagno propõe um descritivismo radical, que nega a centralidade de qualquer norma de referência para o ensino de português, cuja metodologia consistiria no letramento contínuo dos aprendizes, através do qual as atividades de leitura, escrita e reflexão sobre a língua promoveriam o conhecimento dos diversos gêneros textuais, da variação ou mudança linguística e os valores a ela associados. Nessa proposta, o sentido da gramática como objeto de ensino/estudo fica ainda mais nebuloso.

\section{5 À GUISA DE CONCLUSÃO: POR UMA DIDÁTICA DA LÍNGUA PORTUGUESA}

O objetivo de transferir os saberes científicos para o ensino, sem a devida observância à teoria didática, faz emergir nas diferentes propostas uma lista de pontos cegos:

1. A educação tem por objetivo promover a socialização das novas gerações, o que inclui o desenvolvimento de competências sociopolíticas, socioculturais, pessoais, interpessoais e profissionais. Nesse sentido, os processos de ensino-aprendizagem ligados aos saberes gramaticais devem estar relacionados com o desenvolvimento de competências de leitura e escrita, considerando o fato de estarmos numa sociedade letrada. Nas propostas descritivistas, porém, o estudo científico da língua, entendida como fenômeno natural, figura como objetivo central. Assim, a afirmação de que a escola deve promover o letramento dos estudantes não se coaduna com as metodologias de ensino apresentadas. Além disso, não foram realizadas pesquisas empíricas que comprovassem a viabilidade das propostas.

2. As propostas tomam como referência os estudos científicos da linguística pura voltados para a descrição da fala, entendida como expressão da língua natural, cujos resultados buscam transferir para a escrita, código cultural. O naturalismo linguístico rejeita a possibilidade de se intervir sobre a língua para situá-la entre os fatos humanos sujeitos a valoração e normatização, como tantos outros. Desse modo, pretender que os usos escritos se conformem aos usos falados, além de exprimir uma postura paradoxal (não caberia a uma ciência descritiva adotar uma postura normativa sobre qual norma deveria ser a referência para o ensino), significa negar as especificidades da escrita, os valores sociais a ela atribuídos em uma sociedade letrada como a nossa e desconsiderar seu caráter pancrônico. 
3. As propostas pedagógicas, materiais didáticos ou gramáticas elaboradas com base nas pesquisas descritivas, dado seu foco na língua falada, não contemplam todos os aspectos que envolvem o ensino da escrita. Nenhum deles trata, por exemplo, da ortografia, das regras de acentuação, da pontuação, das regras de concordância, regência e colocação pronominal relativas à escrita. Um bom exemplo do descompasso entre fala e escrita diz respeito às formas e aos usos dos pronomes demonstrativos. Os estudos descritivistas afirmam que, no português brasileiro falado, não existe mais a distinção entre os demonstrativos de primeira pessoa este/esta - e os de segunda pessoa - esse/essa - prevalecendo o uso das formas de segunda pessoa seja em referência à primeira ou à segunda pessoa. Contudo, na gramática normativa e na linguística textual, essas formas são vistas como funcionalmente distintas: $\mathrm{o}$ pronome de primeira pessoa tem valor catafórico, e o de segunda, anafórico.

4. O pluralismo teórico adotado nos estudos descritivistas, incluindo as gramáticas pedagógicas baseadas na linguística pura, gera indefinições quanto à terminologia gramatical a ser adotada no ensino, uma vez que cada paradigma de investigação linguística - formalista, funcionalista ou sociolinguístico - se orienta por diferentes nomenclaturas conceituais.

5. As propostas descritivistas não tratam da relação entre competências e conteúdos - conceituais, procedimentais e atitudinais - nem explicitam as concepções de ensino-aprendizagem que as orientam. Desse modo, é possível afirmar que a adaptação das metodologias científicas ao estudo da língua mostra-se inadequada para atingir os objetivos educacionais. Além disso, as propostas não apontam qualquer perspectiva de avaliação da aprendizagem.

Neste texto, apresentei uma breve caracterização da didática como teoria da prática de ensino e suas transformações num contexto acadêmico estruturado segundo os princípios da fragmentação e especialização do saber inerentes ao paradigma científico moderno. Assinalei ainda algumas particularidades da didática quanto às relações que ela estabelece com o saber, destacando sua natureza, ao mesmo tempo, epistemológica, axiológica e praxiológica. Desse modo, certas dicotomias fundamentais da ciência moderna, como objetividade/subjetividade, teoria/prática e ciência pura/ciência aplicada, não fazem sentido no campo da didática.

Demonstrei também que a lógica disciplinar e acadêmica transformou a didática geral numa disciplina incompleta, que desenvolve uma teoria geral de todos os elementos envolvidos na prática educativa, mas que não pode teorizar sobre os objetivos, objetos de ensino, metodologias e práticas avaliativas das disciplinas particulares, o que evidencia a necessidade das didáticas específicas de cada disciplina. Nesse sentido, assumi o pressuposto de que as didáticas específicas devem constituir-se em conformidade com os princípios teórico-metodológicos da didática geral.

Com base nesses postulados, empreendi uma análise de propostas da linguística aplicada lato sensu para o ensino de gramática. Justifiquei a escolha desse objeto por sua relevância nas discussões e propostas para o ensino de português, dada sua importância no imaginário social e nas práticas educacionais e sociopolíticas que envolvem a língua padrão como norma unificadora e constitutiva do estilo de vários gêneros textuais. Paralelamente a isso, a exigência de formação superior para o exercício do magistério torna a questão relevante para a formação profissional dos professores, que devem ser formados para atuar na educação básica em conformidade com as políticas educacionais para esse nível da educação formal.

A análise das diferentes perspectivas do descritivismo - puro, relativista e radical - evidenciou a distância que existe entre as formas de conceber o ensino de português pela linguística aplicada, movida pelo ideal de transferência dos saberes da ciência teórica ao contexto escolar, e a didática da língua, perspectiva de construção de objetos de ensino ainda inexistente no Brasil como área institucionalizada. Em consequência disso, a tarefa de promover a articulação da didática geral com os saberes específicos que compõem o português como disciplina curricular na educação básica tem sido desempenhada pelos gestores das políticas educacionais, a exemplo do que aconteceu nos PCN e agora na BNCC.

A linguística aplicada, coerente com o paradigma positivista, encontra sua razão de ser na defesa intransigente do conhecimento científico como solução para os problemas do ensino de língua, em geral, e da gramática, em particular. Aderindo ao cientificismo, a linguística aplicada promove uma separação entre ensino e didática ao desconsiderar as diferenças que caracterizam as formas de relação com o saber nos campos da ciência e da educação, assim como a natureza diferenciada de seus objetivos. Esse problema fica evidente quando verificamos que as tentativas de transferência dos saberes científicos ao ensino se dão de forma fragmentária, com 
cada disciplina da linguística elaborando propostas de maneira isolada, considerando apenas os aspectos teórico-metodológicos, conceituais e terminológicos relativos ao seu próprio campo. Nesse contexto, a quem caberia promover a articulação dessas diferentes propostas no currículo da educação básica? Esse problema, por si só, já seria suficiente para evidenciar a necessidade de uma didática da língua portuguesa como disciplina responsável por pensar o ensino de maneira global.

Por outro lado, o objetivo de pensar o ensino em toda a sua complexidade exige da didática um diálogo constante com as demais ciências de base ou aplicadas que abordam, de maneira direta ou indireta, aspectos ligados ao ensino. No tocante à relação entre a didática da língua e a linguística, teórica ou aplicada, compete aos didáticos, levando em consideração os objetivos do ensino de língua como prática social e elemento fundamental para a constituição da cidadania, promover ações de crítica e pesquisa dos conhecimentos científicos para avaliar sua pertinência no conjunto dos objetos de ensino que tem compor o currículo escolar.

Logo, não cabe à linguística como ciência aplicada a tarefa de determinar quais devem ser os conteúdos da língua portuguesa como disciplina curricular, embora não se negue a importância de suas reflexões para auxiliar a didática em suas funções crítica, epistemológica e política. A falta de clareza quanto à relação da linguística com a didática está na base da falta de diálogo que se verifica entre o discurso acadêmico que orienta a formação de professores de língua portuguesa, as políticas educacionais e as práticas de ensino na educação básica. Por essa e outras razões, urge o estabelecimento da didática da língua portuguesa como campo institucionalizado de produção de conhecimento sobre o ensino da língua em nosso país.

\section{REFERENCIAS}

ALTET, M. Análise das práticas dos professores e das situações pedagógicas. Trad. Júlia Ferreira e José Cláudio. Porto, Portugal: Editora do Porto, 2000.

ANTUNES, I. Muito além da gramática: por um ensino de língua sem pedras no caminho. São Paulo: Parábola Editorial, 2007.

ANTUNES, I. Língua, texto e ensino: outra escola possível. São Paulo: Parábola Editorial, 2009.

ANTUNES, I. Gramática contextualizada: limpando o pó das ideias simples. São Paulo: Parábola Editorial, 2014.

BAGNO, M. Português ou brasileiro? Um convite à pesquisa. São Paulo: Parábola Editorial, 2001.

BAGNO, M. A norma oculta: língua e poder na sociedade brasileira. São Paulo: Parábola Editorial, 2003.

BAGNO, M. Gramática pra que te quero? Os conhecimentos linguísticos nos livros didáticos de português. Curitiba: Aymará, 2010.

BAGNO, M. Por que estudar uma gramática brasileira? In: CASSEB-GALVÃO, V.; NEVES, M. H. M. O todo da língua: teoria e prática do ensino de português. São Paulo: Parábola Editorial, 2017. p. 97-122.

BAKHTIN, M. Os gêneros do discurso. Trad. Paulo Bezerra. São Paulo: Editora 34, 2016.

BASTIDE, R. Antropologia aplicada. 2. ed. Trad. Maria Lúcia Pereira e J. Guinsburg. São Paulo: Perspectiva, 2009.

BORTONI-RICARDO, S. M. et al. Por que a escola não ensina gramática assim? São Paulo: Parábola Editorial, 2014.

BOUDON, R. A sociologia como ciência. Trad. Francisco Morás. Petrópolis: Vozes, 2010. 
BRONCKART, J-P.; DOLZ, J. A noção de competência: qual é sua pertinência para o estudo da aprendizagem das ações de linguagem. In: DOLZ, J.; OLLAGNIER, E. (org.). O enigma da competência em educação. Trad. Cláudia Schilling. Porto Alegre: Artmed, 2004. p. 29-46.

BUNZEN, C.; MENDONÇA, M. (org.). Múltiplas linguagens para o ensino médio. São Paulo: Parábola Editorial, 2013.

BUNZEN, C.; MENDONÇA, M. (org.). Português no ensino médio e formação do professor. São Paulo: Parábola Editorial, 2006.

CANGUILHEM, G. O normal e o patológico. 6.ed. Trad. Maria Thereza R. de C. Barrocas. Rio de Janeiro: Forense Universitária, 2009.

CASTILHO, A.; ELIAS, V. M. Pequena gramática do português brasileiro. São Paulo: Contexto, 2012.

CAVALCANTI, M. C.; SIGNORINI, I. (org.). Linguística aplicada e transdisciplinaridade. Campinas, SP: Mercado de Letras, 1998.

CHEVALLARD, Y. La transposition didactique. Grenoble: La Penseé Sauvage Editions, 1985.

CHOMSKY, N. Regras e representações: a inteligência humana e seu produto. Trad. Marilda Winkler Avergbug et al. São Paulo: Zahar, 1981.

COHEN, E. G.; LOTAN, R. A. Planejando o trabalho em grupo: estratégias para salas de aula heterogêneas. Trad. Luís Fernando Marques Dorvillé et al. 3. ed. Porto Alegre: Penso, 2017.

COLL. C. (org.) Psicologia da educação. Trad. Cristina Maria de Oliveira. Porto Alegre: Penso Editora, 1999.

COLL, C.; POZO, J. I.; SARABIA, B.; VALLS, E. Os conteúdos na reforma: ensino e aprendizagem de conceitos, procedimentos e atitudes. Trad. Beatriz Affonso Neves. Porto Alegre: Artmed, 2000.

COMENIUS. Didática magna. Trad. Ivone Castilho Benedetti. 3. ed. São Paulo: Martins Fontes, 2006.

CORACINI, M. J.; BERTOLDO, E. S. (org.). O desejo da teoria e a contingência da prática: discursos sobre e na sala de aula. Campinas, SP: Mercado de Letras, 2003.

DOLZ, J.; OLLAGNIER, E. O enigma da competência em educação. Trad. Cláudia Schilling. Porto Alegre: Artmed, 2004.

DOLZ, J. As atividades e os exercícios de língua: uma reflexão sobre a engenharia didática. DELTA, São Paulo v. 32, n. 1, p. 237-260, jan-abr 2016.

FARACO, C. A. Norma culta brasileira: desatando alguns nós. São Paulo: Parábola Editorial, 2008.

GARCÍA, C. M. Formação de professores para uma mudança educativa. Trad. Isabel Narciso. Porto, Portugal: Porto Editora, 1999.

GIMENO SACRISTÁN, J.; GÓMEZ, A. I. P. Compreender e transformar o ensino. 4. ed. Trad. Ernani F. da Fonseca Rosa. Porto Alegre: Artmed, 1998.

GIMENO SACRISTÁN, J. et al. Educar por competências: o que há de novo? Trad. Carlos Henrique Lucas Lima. Porto Alegre: Artmed, 2011. 
GIMENO SACRISTÁN, J. Dez teses sobre a aparente utilidade das competências em educação. In: GIMENO SACRISTÁN, J. et al. Educar por competências: o que há de novo? Trad. Carlos Henrique Lucas Lima. Porto Alegre: Artmed, 2011, p. 13-63.

HADJI, C. Avaliação desmistificada. Trad. Patrícia C. Ramos. Porto Alegre: Artmed, 2001.

HARTMAN, H. J. Como ser um professor em todas as áreas do conhecimento. Trad. Alexandre Salvaterra, Porto Alegre: AMGH Editora, 2015.

KLEIMAN, A. B.; CAVALCANTI. M. C. (org.) Linguística aplicada: suas faces e interfaces. Campinas, SP: Mercado de Letras, 2007.

LABOV, W. Padrões sociolinguísticos. Trad. Marcos Bagno et al. São Paulo: Parábola Editorial, 2008.

LIBÂNEO, J. C. Didática. 2. ed. São Paulo: Cortez, 2013.

LUCKESI, C. C. Avaliação da aprendizagem: componente do ato pedagógico. São Paulo: Cortez, 2011.

MARTINS, M. A.; VIEIRA, S. R.; TAVARES, M. A. (org.). Ensino de português e sociolinguística. São Paulo: Contexto, 2014.

MATTOS E SILVA, R. V. Que gramática ensinar, quando e por quê? In: MATTOS E SILVA, R. V. O português são dois. São Paulo: Parábola Editorial, 2004. p. 79.

MATTOS E SILVA, R. V. Contradições no ensino de português: a língua que se fala x a língua que se ensina. 7. ed. São Paulo: Contexto, 2005.

MÉNDEZ, J. M. A. Avaliar a aprendizagem em um ensino centrado nas competências. In: GIMENO SACRISTÁN, J. et al. Educar por competências: o que há de novo? Trad. Carlos Henrique Lucas Lima. Porto Alegre: Artmed, 2011. p. 233-264.

MOITA LOPES, L. P. Oficina de linguística aplicada: a natureza social e educacional dos processos de ensino-aprendizagem de línguas. Campinas, SP: Mercado de Letras, 1996.

MOITA LOPES, L. P. (org.). Por uma linguística aplicada indisciplinar. São Paulo: Parábola Editorial, 2006.

PAQUAY, L.; PERRENOUD, P.; ALTET, M. CHARLIER, E. (org.) Formando professores profissionais: quais estratégias? Quais competências? 2. ed. Trad. Fátima Murad; Eunice Gruman. Porto Alegre: Artmed, 2001.

PÉREZ GÓMEZ, A. I. Os processos de ensino-aprendizagem: análise didática das principais teorias da aprendizagem. In: GIMENO SACRISTÁN, J.; GÓMEZ, A. I. P. Compreender e transformar o ensino. 4. ed. Trad.: Ernani F. da Fonseca Rosa. Porto Alegre: Artmed, 1998. p. 27-52.

PÉREZ GÓMEZ, A. I. Competências ou pensamento prático? A construção dos significados de representação e de ação. In: GIMENO SACRISTÁN, J. et al. Educar por competências: o que há de novo? Trad. Carlos Henrique Lucas Lima. Porto Alegre: Artmed, 2011.p. 64-114.

PERINI, M. A. Gramática do português brasileiro. São Paulo: Parábola Editorial, 2010.

PERRAUDEAU, M. Estratégias de aprendizagem: como acompanhar os alunos na aquisição dos saberes. Porto Alegre: Artmed: 2009. 
PERRENOUD, P. Avaliação: da excelência à regulação das aprendizagens - entre duas lógicas. Trad. Patrícia Chittoni Ramos. Porto Alegre: Artmed, 1999.

PERRENOUD, P. Pedagogia diferenciada: das intenções à ação. Trad. Patrícia Chittoni Ramos. Porto Alegre: Artmed, 2000.

PERRENOUD, P. A pedagogia na escola das diferenças: fragmentos de uma sociologia do fracasso. 2. ed. Trad. Cláudia Schilling. Porto Alegre: Artmed, 2001.

PERRENOUD, P. A prática reflexiva no ofício de professor: profissionalização e razão pedagógica. Trad. Cláudia Schilling. Porto Alegre: Artmed, 2002.

PERRENOUD, P. Desenvolver competências ou ensinar saberes? A escola que prepara para a vida. Trad. Laura Solange Pereira. Porto Alegre: Penso, 2013.

PETITJEAN, A. Importância e limites da noção de transposição didática. Fórum Linguistico, Florianópolis, v. 5, n. 2, p. 83-116, jul./dez. 2008.

POZO, J. I. Aprendizes e mestres: a nova cultura da aprendizagem. Trad. Ernani Rosa. Porto Alegre: Artmed, 2002.

RODRÍGUEZ, J. B. M. A cidadania se torna competências: avanços e retrocessos. In: GIMENO SACRISTÁN, J. et al. Educar por competências: o que há de novo? Trad. Carlos Henrique Lucas Lima. Porto Alegre: Artmed, 2011. p. 115-160.

ROJO, R. Letramentos múltiplos, escola e inclusão social. São Paulo: Parábola Editorial, 2009.

ROJO, R.; MOURA, E. (org.) Multiletramentos na escola. São Paulo: Parábola Editorial, 2012.

SANTOS, M. B. A interdisciplinaridade na formação do professor de língua portuguesa. In: SOARES, S. R.; LIEGE, S. F.; MACHADO, A. L. Desenvolvendo competências na universidade: perspectivas e práticas inovadoras na formação de profissionais. Salvador: EDUNEB, 2017.

SANTOS, M. B. dos. A licenciatura como ato performativo: reflexões sobre a formação universitária do professor de Língua Portuguesa.DELTA, São Paulo, v. 34, n. 4,p. 1159-1185, dez. $2018 . \quad$ Disponível em: http://www.scielo.br/scielo.php?script=sci arttext\&pid=S0102-44502018000401159\&lng=en\&nrm=iso. Acesso em: 16 maio 2019.

SANTOMÉ, J. T. Evitando o debate sobre a cultura no sistema educacional: como ser competente sem conhecimento. In: GIMENO SACRISTÁN, J. et al. Educar por competências: o que há de novo? Trad. Carlos Henrique Lucas Lima. Porto Alegre: Artmed, 2011. p. 161-197.

SAUSSURE, F. Curso de linguística geral. 26. ed. Trad. Antônio Chellini, José Paulo Paes, Izidoro Blikstein. São Paulo: Cultrix, 2004.

TARDIF, M.; LESSARD, C. O trabalho docente: elementos para uma teoria da docência como profissão de interações humanas. 9. ed. Trad. João Batista Kreuch. Petrópolis, RJ: Vozes, 2014.

TRAVAGLIA, L. C. Gramática e interação: uma proposta para o ensino de gramática. 13. ed. São Paulo: Cortez, 2009.

VIEIRA, S. R.; BRANDÃO, S. F. (org.). Ensino de gramática: descrição e uso. São Paulo: Contexto, 2007.

VIANIN, P. Estratégias de ajuda a alunos com dificuldades de aprendizagem. Trad. Fátima Murad. Porto Alegre: Penso, 2013. 
WEINREICH, U.; LABOV, W.; HERZOG, M. I. Fundamentos empíricos para uma teoria da mudança linguística. Trad. Marcos Bagno. São Paulo: Parábola Editorial, 2006.

WEINSTEIN, C. S.; NOVODVORSKY, I. Gestão da sala de aula: lições da pesquisa e da prática para trabalhar com adolescentes. 4. ed. Trad. Luís Fernando Marques Dorvillé. Porto Alegre: AMGH, 2015.

ZABALA, A. A prática educativa: como ensinar. Trad. Ernani F da F. Rosa. Porto Alegre: Artmed, 1998.

ZABALA, A. Enfoque globalizador e pensamento complexo: uma proposta para o currículo escolar. Trad. Ernani Rosa. Porto Alegre: Artmed, 2002.

ZABALA, A.; ARNAU, L. Como aprender e ensinar competências. Trad. Carlos Henrique Lucas Lima. Porto Alegre: Artmed, 2010.

ZABALA, A.; ARNAU, L. O objetivo da educação por competências é o pleno desenvolvimento da pessoa. In: ZABALA, A. et al. Didática geral. Trad. Carlos Henrique Lucas Lima. Porto Alegre: Penso, 2016. p. 1-24.

ZILLES, A. M. S.; FARACO, C. A. (org.). Pedagogia da variação linguística: língua, diversidade e ensino. São Paulo: Parábola Editorial, 2015.

\section{() $\circledast \Theta$}

Recebido 03/12/2018. Aceito em 17/05/2019. 